\title{
Candidates for the Priesthood in Poland A.D. 2020: A Research Report
}

\author{
KRZYSZTOF PAWLINA \\ Catholic Academy of Warsaw \\ kpawlina@wmsd.mkw.pl, ORCID: 0000-0002-3855-6720
}

\begin{abstract}
The article essentially aims at answering who were the Polish young men wishing to become priests in 2020 as compared with the candidates who entered Polish seminaries in 2000. The answer was based on quantitative and qualitative surveys conducted in 2000 and 2019 among seminarians at the very beginning of their priestly formation. The questionnaires, though exposing great cognitive possibilities, cannot measure what concerns the mystery of vocation or faith. Despite these limitations, the obtained results have allowed us to find out, for example, where the seminarians came from and what their backgrounds were. They also show their interests, the level of their general and religious knowledge as well as their values. Of importance was to get to know their visions of the priesthood and the Church. The present paper, as a synthesis of the study published in book form, gives a profile of the contemporary candidate for the priesthood. The results of the research can be used by formators and all those who make arrangements for the introduction of the new Ratio Institutionis in Poland.
\end{abstract}

Keywords: seminarian, vocations, candidates for the priesthood, youth

In 2000, for the first time in Poland, sociological research was carried out in all major seminaries. At that time, candidates for the priesthood who had just started their first year of study were examined. ${ }^{1}$ Nearly twenty years later, the study was repeated. ${ }^{2}$ Two decades is almost a generational change. Therefore, the following questions were asked again: Who are these young men? Are they priest material? Have there been any changes in the mentality of those entering the seminary during this time?

In order to obtain answers to the above questions, a new questionnaire was developed on the basis of the original one. ${ }^{3}$ Some questions were reformulated, and

1 In 2000, 925 candidates were examined, which constituted 100\% of all those who entered the major seminaries at that particular time. A comprehensive study concerning the research is available in the publication: Pawlina, Kandydaci do kapłaństwa trzeciego tysiaclecia.

2 In 2019, 289 candidates who began the first year of priestly formation were surveyed (questionnaires were not sent back by four seminaries, but the number of candidates in these institutions was 11 men in total). A full analysis and comprehensive approach to the problem can be found in: Pawlina, Powotania kapłańskie AD 2020.

3 The original questionnaire consisted of 88 questions, while the new one - Powolania diecezjalne 2019 - 91 questions. The research was conducted after the candidates had been admitted to the seminar- 
some new added. The results of the sociological analyses have created an opportunity to present the profile of the contemporary candidate for the priesthood in Poland. The following article is a synthesis of the research report published as a book.

\section{Family Context}

\subsection{The Social Situation of the Candidates' Families}

The first and most important educational environment of a young person is the family. It is in the family that faith is formed, vocation is discovered, and many other qualities that will be crucial to social life are acquired. The example of the parents subconsciously influences the image of God and the way of treating the Church community as a family of God's children. Therefore, the role of the family cannot be overestimated, and its influence on the formation of the personality, on sensitivity and pro-social attitudes of the future priest is particularly important.

Among the basic questions that outline the profile of the candidates for the seminary, the most obvious one was the presence of the parents in their lives. Exactly $90 \%$ of the respondents replied that both parents were still alive (in $2000-90.4 \%$ ), only the mother - was indicated by $7.6 \%$ of them (in $2000-8.1 \%$ ), only the father $-1 \%$ (in $2000-0.9 \%$ ), while in the case of $1 \%$ of the respondents both parents were dead (in $2000-0.3 \%$ ). In fact, the distribution of the answers is similar to that of 20 years ago. The higher percentage of orphaned people can be explained by the fact that now older candidates join the seminary.

The fact of having both parents does not automatically mean being under their direct care or being brought up by them. $84.1 \%$ of the candidates for the priesthood grew up in a two-parent family (in $2000-83.2 \%$ ), in a family that has lost one parent $-3.1 \%$ (in $2000-4.3 \%$ ), in a divorced or separated family $-6.6 \%$ (in $2000-5.7 \%$ ), in a remarried family $-1.7 \%$ (in $2000-2.7 \%$ ), and in a single mother family $-1.7 \%$ (in $2000-2.5 \%$ ).

Apart from their parents, young men's closest companions are brothers and sisters. Priestly vocations from single child families constitute a definite minority $6.6 \%$ (in $2000-8.2 \%$ ). As many as $92 \%$ of the respondents admitted having siblings (the result does not add up to $100 \%$ due to the lack of answers in some surveys). Most of the respondents were brought up in the company of one brother or one sister $39.4 \%$ (in $2000-38.1 \%$ ), two siblings were indicated by $26 \%$ (in $2000-29.3 \%$ ), and

ies, but before their lectures or talks started. The point was that the respondents should not yet undergo any formation processes, and that their answers were as authentic as possible. 
three $-13.1 \%$ (in $2000-13.2 \%$ ), for four $-6.9 \%$ (in $2000-4.9 \%$ ), for five or more $6.6 \%$ (in $2000-2.7 \%$ ). The average number of children in the families of candidates for the priesthood was exactly two (in $2000-2.91$ ). The decline in the fertility rate of families is therefore extremely progressive, although it is noteworthy that the largest group of candidates still comes from families with two children.

\subsection{Parents' Age, Education and Profession}

Taking into account the parents whose sons began their seminary formation, it is worth noting that $6.7 \%$ of the mothers were under 40 years of age (in $2000-10.7 \%$ ). The largest group of parents is in the $46-50$ age group - $28.3 \%$ of the mothers and $26.9 \%$ of the fathers (in $2000-27.7 \%$ and $34.6 \%$, respectively). While in the group of the fathers the indicated age range still maintained the dominant position, there was a shift in the mothers' group. In 2000, the greatest number of vocations was declared by the respondents whose mothers were in the $41-45$ age group (39.1\%). Currently, this group consists of only $23 \%$ of the respondents. Taking into account the entire survey, it was calculated that the average age of the mother of the contemporary seminarian is 49.5 years (in $2000-46.6$ ), and of the father - 51.7 years (in $2000-49.3$ ). This increase is probably due to the fact that more and more people with some life experience (not only high school graduates) enter the seminary, as well as the increased representation of the youngest siblings (when the age of the parents is already more advanced than in the case of the firstborn).

Family upbringing, apart from the religious aspect, is probably significantly related to the social and professional aspirations of the parents. What kind of education do the families of the candidates for the priesthood have? The first reflection that arises from the analysis of the answers obtained is that in many families the educational attainment of the mother and father is fairly significantly diversified. Among the mothers, higher education is most common - 33.2\% (in 2000 - 13.3\%) and basic vocational education is in second place $-32.9 \%$ (in $2000-29 \%$ ). Among the fathers, basic vocational education dominates $-46.4 \%$ (in 2000 - 43.6\%) over higher education $-21.1 \%$ (in $2000-10.3 \%$ ). From the above data, the following two conclusions can be drawn: firstly, in the homes of the candidates for the priesthood, the mothers have significantly better education; secondly, over the last two decades the role of families with higher education has more than doubled. On the other hand, the number of the respondents whose parents have a primary school or lower level of education decreased: for the mothers this percentage is now 2.4\% (in $2000-13.8 \%$ ), for the fathers $3.5 \%$ (in $2000-12.5 \%$ ). To sum up, more and more young people from intellectual families join seminaries. In this case, the priesthood is probably not an option for gaining a higher social status or satisfying material needs, but voluntarily and reflectively choosing a specific path of spiritual and intellectual development. 
Questions about education and occupation do not yet provide a complete picture of the social situation in the families of candidates for the priesthood. Thus it is worth considering the parents' professional situation. Currently, $70 \%$ of the mothers and $77.7 \%$ of the fathers work professionally (in $2000-48.4 \%$ and $58.3 \%$, respectively), $4.2 \%$ of the mothers and $3.8 \%$ of the fathers are unemployed (in $2000-9.5 \%$ and $6.9 \%$, respectively), $3.2 \%$ of the mothers and $6.1 \%$ of the fathers are pensioners (in $2000-16 \%$ and $16.6 \%$ respectively). These data indicate a significant increase in the professional activity of the parents and a decrease in the group of the unemployed and the pensioners.

\section{Cultural and Intellectual Quality of the Vocations}

\subsection{Candidates' Age and Education}

The decision to enter a seminary is usually made at a young age. Graduating from secondary school naturally forces a person to specify their plans. It is during this period that the greatest number of priestly vocations is born. In Poland the average age for men starting their studies in the seminary is currently 21 years and 4 months (in 2000 - 20 years and 2 months), with the dominant age of 19. It is the most common age for obtaining a high school diploma (matura). The candidates who were aged up to 20 inclusive constitute $64 \%$ of all the respondents (in $2000-76.6 \%$ ), the group of the candidates aged $21-25$ is $23.9 \%$ (in $2000-18.9 \%$ ), aged $26-30$ is $5.9 \%$ (in $2000-2.1 \%$ ) and over 30 is $4,5 \%$ (in $2000-0.9 \%$ ).

The average age has increased by more than a year over the past 20 years. This increase is a consequence of the fact that many more men over $30-4.5 \%$ (in 2000 $0.9 \%$ ) now respond to their vocation to the priesthood.

A typical educational level of a candidate for the priesthood is secondary school 46.6\% (in $2000-45.7 \%$ ). Graduates of technical secondary schools constitute a much smaller group - $18.3 \%$ (in $2000-26.8 \%$ ). There are hardly any vocations originating from vocational secondary schools $-0.7 \%$ (in $2000-11.9 \%$ ) and post-secondary schools - 1\% (in $2000-1.7 \%$ ). The negligible percentage of vocations born in technical colleges is the result of the reduction and phasing out of secondary vocational education in Poland in the recent decades. Overall, $65.6 \%$ of the candidates for the priesthood have secondary education. Twenty years ago, this group comprised $84.4 \%$ of the candidates. The rest of the respondents began university programmes earlier, with varying results. $15.9 \%$ of the respondents did not complete their Bach- 
elor's studies (in $2000^{4}-2.3 \%$ ), $7.9 \%$ (in 2000 - 1.7\%) completed their Bachelor's studies or post-secondary schools. 3.1\% did not complete their Master's programmes (in $2000-8.5 \%$ ), while $6.9 \%$ of the respondents have completed their Master's studies (in $2000-2.4 \%$ ).

The results of the study indicate that the number of those who began Bachelor's or Master's study programmes after graduating from secondary school has doubled. Currently, their percentage is $33.8 \%$ compared to $14.9 \%$ in 2000 . Moreover, the percentage of the candidates for the priesthood who completed their Master's studies is almost three times the percentage in $2000-6.9 \%$ compared to $2.4 \%$.

This segment of research was supplemented by the question about work experience. It turns out that over half of the candidates (51.2\%) already worked professionally (in $2000-18.5 \%$ ), and $48.1 \%$ did not (in $2000-80.7 \%$ ). ${ }^{5}$ The high rate of those with work experience, with the previously obtained results on the respondents' education and age, suggests that some young people may have had only short periods of employment, e.g. part-time holiday jobs or internships. Nevertheless, the percentage of the candidates declaring taking up some professional activity before entering the seminary has almost tripled over the past twenty years. This may mean that the candidates for the priesthood have greater awareness and experience in discerning their path of life.

\subsection{Candidates' Spheres of Interests}

Candidates for the priesthood, apart from broadly understood social interests, have individual interests, preferences and hobbies. What kind of interests are these?

Music was listed first - 61.9\% (in $2000-50.9 \%$ ), then sport - 45.3\% (in $2000-$ $50.9 \%$ ), tourism $-45 \%$ (in $2000-47,9 \%$ ), film - 38.8\% (in $2000-38.3 \%$ ), computer $-33.3 \%$ (in $2000-24.4 \%$ ), theatre $-20.4 \%$ (in $2000-15$, 5\%), DIY and technical activities - 19.4\% (in $2000-18.6 \%$ ), photography and filming - 15.5\% (in 2000 $9.9 \%$ ) and collecting $-7.6 \%$ (in $2000-7.8 \%$ ). There are no significant differences in the interests of young people over the last two decades. The spheres of interests also include reading books and newspapers. Therefore, future priests were asked about the number of books read during the last year. It turned out that $9 \%$ of the respondents had not read any book (in $2000-5.4 \%$ ), $44.6 \%$ of the respondents declared that they had read at least five books (50.9\% in 2000), more than ten books $-10.4 \%$ of the respondents (in $2000-18.2 \%$ ). $34.9 \%$ of the future clergymen (in $2000-11.8 \%$ ) read dailies or information portals. $8.3 \%$ were interested in reading the news on

4 The 2000 survey also included the question about "completed / not completed post-secondary education" among its education categories. The 1999 Bologna Process introduced a new category into higher education - the Vocational Bachelor.

5 The results do not add up to $100 \%$ due to the lack of responses. 
a daily basis (9.4\% in 2000). The remaining group read the press two or three times a week (18.7\%), once a week (10\%) or occasionally (27.7\%). In 2000, the corresponding results were as follows: two or three times a week $-24.4 \%$, once a week $-15 \%$ and occasionally - $39.1 \%$.

Summing up the readership of the press among future priests, it can be stated that the number of those interested in daily reading has increased significantly. Perhaps it is related to the increasing access to the Internet sources. On the other hand, the number of those interested in any access to information decreased by over $10 \%$. While reading the press is becoming more and more popular, in the category of book readership the results show the opposite tendency. The number of those declaring a lack of interest in reading anything has almost doubled in the past year, and the group of those reading more than five books a year has decreased by nearly $20 \%$.

\subsection{Religious Knowledge}

One would expect candidates for the priesthood to possess a certain base of religious knowledge. Therefore, subsequent questions concerned topics related to the catechism as well as the broadly understood knowledge of the religious situation in the Catholic Church. When asked about the names of the two predecessors of John Paul II, $83.3 \%$ (in $2000-47.8 \%$ ) of the respondents gave the correct answer. The next question concerned the knowledge of the titles of papal encyclicals. More than half of the respondents $(54.3 \%$ ) could not indicate any title (in $2000-42.6 \%$ ). This means a decline in the knowledge of the papal teaching among young people.

The next set of questions was related to the knowledge of the catechism. When asked about the number of the requirements to receive the sacrament of Penance, $84.8 \%(89.4 \%$ in 2000$)$ gave the correct answer. When asked for details, i.e. the correct names of the five elements, were given by $70.2 \%$ (in $2000-72.8 \%$ ), and none was given by $13.5 \%$ (in $2000-15 \%$ ). Future priests were also asked about the most important Christian commandments. The commandment of love was indicated by $81.7 \%$ of the respondents (in $2000-83.9 \%$ ), another commandment $-15.6 \%$, and $2.8 \%$ did not give any answer.

The names of the Evangelists were another point checking the candidates' religious knowledge. All the Evangelists' names were mentioned correctly by $92.7 \%$ (in $2000-93.3 \%) .1 .4 \%$ did not mention any name. The others named one, two or three Gospel authors.

The last of the tasks concerned the identification of a non-monotheistic religion. The correct answer was given by $87.2 \%$ of the respondents (in $2000-66.6 \%$ ).

The presented results of the research on religious knowledge show a general decrease - by several or so percentage points - in almost all of the issues discussed. The simplest explanation for this fact seems to be the weakness of religious education 
classes and the progressive secularization of the society. However, there is a hypothesis that there are people who were not very religious or practicing Catholics and yet decided to enter the seminary at a more mature age after having lost their knowledge of the catechism.

Young people spend a lot of time surfing the web. How is it expressed with the candidates for the priesthood?

Only one person admitted to not using the Internet at all. More than half of the candidates (51.5\%) indicated that they used the Internet for two hours a day or more. This means that they devoted relatively the largest part of their free time to it; $31.8 \%$ of the respondents used it for 1-2 hours. The biggest concern is the fact that as many as $15.2 \%$ of candidates for the priesthood use the Internet for more than four hours a day, which means they are on the verge of being addicted.

\section{Factors and Circles that Strengthen or Weaken One's Vocation}

\subsection{Fears}

In addition to aspirations and ambitions, man experiences various fears related to both the present and the future. These fears may result from the influence of the external world, but also from being aware of one's own imperfections or from the pressure to choose one's life path.

The candidates for the priesthood were presented with eleven categories of concern, of which they could identify three. Most fears concerned the loss of a loved one $34.6 \%$ (in $2000-25.2 \%$ ), the feeling of loneliness, lack of friends - 32.9\% (in 2000 $20.1 \%$ ) and severe illness, loss of health or disability - 28.4\% (in $2000-25.6 \%$ ). In further places it was indicated: departure from one's ideals - 28\% (in $2000-26.6 \%$ ), realizing at the end of life that it was empty and wasted - 28\% (in $2000-37.9 \%$ ), fear of human hatred and envy - 26.3\% (in $2000-37.9 \%$ ), lack of success in the implementation of plans related to study or work - 13.1\% (in $2000-12.5 \%$ ), a colourless and boring life $-9.7 \%$ (in $2000-6.1 \%$ ), being ridiculed and embarrassed $-9.3 \%$ (in $2000-5.4 \%$ ), poverty $-9.3 \%$ (in $2000-5.3 \%$ ).

\subsection{Participation in the Altar Service}

For many decades, altar-boys have been the most basic and universal formation group for male youth. As part of the research, the candidates for the priesthood were asked about their relationship with the community of altar servers. When asked if they had been altar boys before entering the seminary, $84.4 \%$ of the respondents an- 
swered "yes" (in 2000 - 82.9\%), and 15.6\% denied performing such duties (in 2000 $16.5 \%)$. Therefore, the replies confirm that the community of altar-boys remains one of the main sources of vocations.

The next question was about the length of time they served at the altar. It turns out that their participation in the altar service often started immediately after their First Communions. As many as $44.3 \%$ of the respondents declared that they had served for $9-12$ years (in $2000-52.5 \%$ ), while $14.9 \%$ served for 13 years or longer (in $2000-9.6 \%$ ). $13.8 \%$ of the respondents served up to four years (in $2000-16 \%$ ), and $10.4 \%-5-8$ years (in $2000-21.1 \%$ ). Consequently, the vast majority of the candidates have many years of experience in the liturgical community of the altar, which probably influenced their decisions to join the seminary. Detailed research on the duration of the altar service revealed a wide time frame: from three months to thirteen years. The highest percentage of vocations was after 10 years of this service $-17.6 \%$ of the respondents, after 11 years $-12.8 \%$ and after 12 years $-8.3 \%$. So it seems that those who began their altar service right after their First Communions often decided to enter the seminary after completing their secondary school or technical college education. This pattern of reaching a mature decision concerning vocation to the priesthood concerns $38.7 \%$ of the surveyed group.

\subsection{Participation in Religious Communities and Groups}

Those who enter the seminary have often undergone active formations in various types of religious groups and associations. More than half of the surveyed participants $(67.5 \%)$ admitted that they had belonged to some community other than that associated with the altar service (in $2000-57.4 \%$ ). Only a third of the candidates (32.5\%) had no additional communal formation (in $2000-41.8 \%$ ).

A group of 195 candidates who confirmed their participation in various Catholic groups were then asked to name them. The question was open-ended, so as many groups as applied could be given. The Light-Life Movement (Oaza) was indicated most frequently - 33.3\% (in $2000-42.6 \%$ ). Subsequently, vocations were born in such movements as: the Catholic Youth Association - 11.8\% (in $2000-28.1 \%$ ), Academic Ministry and Youth Ministry - 11.3\% (in $2000-2.3 \%$ ), parish and local youth communities $-10.8 \%$, rosary and prayer groups $-8.2 \%$, parish choirs, other choirs and artistic groups - 7.2\% (in $2000-6.8 \%$ ), the Youth Apostolate Movement and other apostolic groups - $6.2 \%$ (in $2000-4 \%$ ), Caritas groups and parish volunteering - 5.6\%, communities of the Renewal in the Holy Spirit - 4.1\% (in 2000 $9.6 \%$ ), the Neocatechumenate $-3.6 \%$. Among the large nationwide communities, the following were also mentioned: the Movement of Pure Hearts, the School of New Evangelization, the Union of Scouts of the Republic of Poland and Scouts of 
Europe, pilgrimage groups, Bible circles and the Covenant of Mercy. A separate category of the respondents was those who indicated other than the above-mentioned Catholic movements - 17.9\% (in $2000-19.8 \%$ ).

\subsection{Third Parties Supporting the Intention to Enter the Seminary}

People declaring their intention to enter the seminary usually provoke a specific reaction in their interlocutors, starting from the closest ones through their chaplains, friends, teachers, etc. It may be a favourable or unfavourable reaction to the decision. In the next block of questions, the influence of the opinion of the community on shaping vocation to the priesthood was examined.

Respondents could provide more than one answer to the first question. It was necessary to indicate those who supported the intention of starting their seminary studies. Among the answers provided, the first two were clergymen: some priest $81 \%$ (in $2000-69.2 \%$ ) and their parish priest - 80.6\% (in $2000-75.7 \%$ ). The other responses included: the mother $-74.7 \%$ (80.9\%), some friend - 73\% (in $2000-46.5 \%$ ), the father $-62.3 \%$ (in $2000-62.5 \%$ ), the grandmother or grandfather $-56.7 \%$ (in $2000-52.6 \%$ ), some sibling - 53.6\% (in $2000-44.5 \%$ ), a religious instruction teacher $-52.2 \%$ (in $2000-42.9 \%$ ), other family members - 50.5\% (in $2000-32.4 \%$ ), teachers - 27\% (in $2000-23.2 \%$ ) and someone else - 15.2\% (in $2000-10.2 \%$ ). Compared to the previous survey, the distribution of the indicated answers did not change much, while the support of the clergymen and religious instruction teachers (known to the candidates) on the candidates' decisions increased. Perhaps we owe it to more mature vocations which raise less concern of the chaplains. The rate of the teachers' support remains relatively low.

\subsection{Opponents of the Decision to Enter the Seminary}

The decision to enter the seminary sometimes causes negative reactions in the closest social environment of the candidate. Only less than half of the respondents (40.1\%; in $2000-45.7 \%)$ declared that they had not met with disapproval of their intentions by third parties. The rest of the candidates indicated those opposing their decision, respectively: friends $-34.6 \%$ (in $2000-34.9 \%$ ), other family members $20.4 \%$ (in $2000-13.5 \%$ ), siblings $-15.9 \% \%$ (in $2000-7.2 \%$ ), the mother $-13.1 \%$ (in $2000-4.9 \%$ ), a teacher $-10.7 \%$ (in $2000-10.8 \%$ ), the father $-9.3 \%$ (in 2000 $7.8 \%$ ), a grandmother or grandfather $-8.7 \%$ (in $2000-3.1 \%$ ), a religious instruction teacher $-2.4 \%$ (in $2000-0.1 \%$ ), a parish priest $-1 \%$ (in $2000-0.9 \%$ ), a priest $-1 \%$ (in $2000-1.1 \%$ ), someone else $-4.8 \%$ (in $2000-6.7 \%$ ).

It should be noted that despite the generally lower level of disapproval towards the decision to enter the seminary, the disapproval is currently stronger among fam- 
ily members: distant relatives ( +6.9 percentage points) and the immediate family, i.e. siblings $(+8.7$ percentage points), the mother $(+8.2$ percentage points), a grandmother and grandfather $(+5.6$ percentage points $)$ and the father $(+1.5$ percentage points). This increase in the level of disapproval can be explained by the expanding secularization of the society, a decrease in the social prestige of the priest, and perhaps also the declining fertility rate of families who find it difficult to accept the fact that their sons decide to give up professional education or founding a family.

\section{Candidates' Religiousness}

\subsection{Religious Experience}

The primary environment for shaping faith is the family. The parents are indicated as the first and primary teachers of life, including religious life. Candidates for the priesthood were asked about their fathers and mothers' attitude towards faith. Their responses should not be taken as an objective assessment of the parents' religiosity but rather as the sons' opinions on the patterns received in the family home.

The respondents indicated that the mother was usually more religious than any other family member. Her attitude as deeply religious or religious was defined by a total of $88.2 \%$, while in the case of the father - a total of $70.9 \%$ (in 2000 , respectively: $92.4 \%$ and $73.6 \%$ ), of which the fundamental difference between the parents (in favour of the mothers) occurs mainly in the category of deeply religious people.

The group of parents who are undecided on the matters of faith but attached to the religious tradition is not represented in large numbers. The mothers were indicated by $5.5 \%$ of respondents, and the fathers by $12.8 \%$ (in 2000, respectively: $4.8 \%$ and $11.5 \%)$. On the other hand, the group of indifferent parents or non-believers constitutes an even smaller percentage: $3.1 \%$ among the mothers and $7.9 \%$ among the fathers (in 2000: $1.2 \%$ and 6.9\%, respectively). Research has shown that a religious family continues to be the most valuable resource for priestly vocations. On the other hand, the percentage of people - although still small - declaring their parents' indifference to the matters of faith is slowly increasing. This trend shows that some youth are able to find their way to God, even though they do not experience a positive example from one or both parents. As in 2000, it can be stated that the religiosity brought out of the home was owed by the candidates to a slightly greater extent to the mothers than to the fathers.

The following instances concerned the most important sources of the candidate's faith. The respondents could choose three answers and indicate the hierarchy of their 
importance. As the primary factor, most respondents indicated the tradition and upbringing in the family $-28.7 \%$ (in $2000-24.5 \%$ ), the second was going to church, the influence of sermons and priests - 24.9\% (in $2000-24.9 \%$ ), in the third place life experiences - 18.3\% (in $2000-8 \%$ ), and in the fourth - personal thoughts and beliefs $-17.6 \%$ (in $2000-27.1 \%$ ).

There is a noticeable increase in the importance of religious education at home and an even greater impact of personal experiences on the decisions made. On the other hand, the personal thoughts and beliefs of the respondents, which in the previous survey were the most frequently indicated factor of faith, lost their significance. This may be a sign of the diminishing individualization of faith in favour of the development of communal elements both at home and in the wider environment.

Summing up, the three basic factors in shaping faith given by the candidates are: going to church, listening to sermons and meeting with priests was the primary factor $-83.4 \%$ (in $2000-76 \%$ ), secondly, tradition and education in the family $-67.5 \%$ (in $2000-67.2 \%$ ), thirdly - personal thoughts and beliefs - 63.7\% (in 2000-69.8\%), life experiences $-60.6 \%$ (in $2000-37.6 \%$ ) came in the fourth place.

The number of the responses indicating a different (unspecified) factor stimulating faith nearly doubled - 9.7\% (in $2000-5.5 \%$ ). Thus, the largest increase was recorded in the category of personal experiences as well as participating in church life, which seems to confirm the thesis that the contemporary candidate for the priesthood is a person who actively seeks faith on the level of ecclesial life, perhaps in the liturgy, in community or in personal contacts with priests.

Youth is the time of life when one looks for a purpose, the real sense of life. So what gives meaning to the lives of candidates for the priesthood?

Most of the respondents declared: 'religious faith' and 'some other factor' - $61.9 \%$ (in $2000-42.7 \%$ ), "religious faith only" - 28\% (in $2000-44.8 \%$ ), first of all "some other factor," and "faith too" - 3.1\% (in $2000-3.7 \%$ ). The meaning of life beyond faith (in something else) was declared by $4.2 \%$ of candidates for the priesthood (in $2000-1.6 \%)$.

When asked whether faith helps them in everyday life, a positive answer was given by $91 \%$ of the respondents (in $2000-90.9 \%$ ), the answer "probably yes, sometimes" $-7.3 \%$ (in $2000-8.1 \%$ ), none of the respondents indicated a negative answer. When asked if only religious faith can give a person support and a sense of security, the candidates for the priesthood stated as follows: "yes" - 53.3\% (in 2000 $73.5 \%$ ), "depending on the situation" - 36.3\% (in $2000-20.4 \%$ ), "no" - 4.2\% (in $2000-2.1 \%)$.

These questions show the young people's growing scepticism about faith. Perhaps it does not concern the mere dogmas or foundations of religiosity, but there is a clear conviction that faith has a "competitor" (not specified in this study) which is necessary to complete the individual image and meaning of human life. As compared 
with the earlier statements, one can guess that apart from faith, factors such as patriotism or other general human values are becoming increasingly more valuable for young people.

Can the experience of God's nearness affect one's calling? In the next question which did not specify what sense of proximity to God it was - 78.9\% of the respondents admitted having such an experience (in 2000 - 67\%), 3.5\% did not admit it (in $2000-4.6 \%$ ), and that it was difficult to say $-17.6 \%$ (in $2000-26.4 \%$ ). This shows that the group of seminarians personally experiencing the proximity to God has grown significantly. The experience of God's presence is one of the most subjective and difficult elements to diagnose in this study. However, the respondents were asked to try to describe their experiences in the form of an open statement. Among those who declared an evident perception of God's presence and action in their lives, most respondents experienced His existence in the Eucharist, sacraments and adoration of the Blessed Sacrament - 30.3\% (in 2000 - 16.9\%), then while praying, speaking to God, reflecting on the Word of God, meditating - 22.8\% (in $2000-18.4 \%$ ), in difficult life situations $-21.5 \%$ (in $2000-24.2 \%$ ), in everyday life, in nature, in another person - 9.2\% (in $2000-16.6 \%$ ), in connection with the vocation to the priesthood $6.1 \%$ (in $2000-4.8 \%$ ), when God heard their prayers - 4.4\% (in $2000-2.9 \%$ ), during pilgrimages and visiting special places - 3.5\% (in $2000-5.2 \%$ ), during retreats $1.8 \%$ (in $2000-7.3 \%$ ). Moreover, a large group of the respondents (20.2\%) did not indicate any of the above-mentioned situations, confirming, however, the sense of God's presence in other circumstances (in 2000 - 13.9\%). At the same time, 27.2\% of the surveyed group described their experiences of God's presence without relating them to any specific circumstances (some respondents included more than one type of experience - the percentages do not add up to 100\%).

The analysis of the responses shows that Christians experience God's nearness more and frequently during their daily prayerful lives: Holy Mass, sacraments and adoration, as well as while praying, talking to God, meditating on his Word and reflecting. Yet, the experience of his presence is weaker when participating in some extraordinary forms of pastoral ministry: pilgrimages or retreats. On the one hand, this may indicate a crisis of retreats (especially during the so-called school retreats), and on the other, perhaps a conscious participation of the young in the liturgy of the Church and in reading the Word of God is increasing.

\subsection{Religious Faith}

Looking at the views of the young generation on faith, it is impossible to ignore the eschatological questions related to the existence of the ultimate. In a world that increasingly denies the existence of eschatological realities, candidates for the priesthood have shown a far-reaching unanimity in confirming the teaching of the Church. When asked about the belief in the existence of hell, $99 \%$ of the respondents gave 
a positive answer (in 2000 - 95.2\%), and the belief in the existence of Satan was also confirmed by $99 \%$ (in $2000-96.6 \%$ ). The increase in the belief in the existence of hell and Satan compared to the 2000 study can be explained by the increasingly common teaching of the exorcists, as well as by numerous public and private revelations, widely described and commented on in religious media.

What is the most important duty of Catholics? This issue seems to be one of the key questions addressed to the candidates for the priesthood. Carrying out their pastoral ministry in the future and supporting others on the path of faith, they should have a properly formed hierarchy of the Christian values. Is this true in reality? Most people indicated loving God as the most important Catholic duty - 64.4\% (in 2000 $52.8 \%$ ), obeying the commandments came second - 15.2\% (in $2000-25.4 \%$ ), in the third place - loving your neighbour - 14.9\% (in $2000-13.2 \%$ ), and in the fourth one - obedience to the Church - $1.7 \%$ (in $2000-3.5 \%$ ).

It can be said that in twenty years there has been a growing awareness of the attitude of love as the primary disposition for fulfilling the Christian vocation. On the other hand, the attachment to juridical obeying the law has decreased - even if obeying the commandments implies the fulfilment of the most important of them the commandment of love.

\subsection{Religious Practices}

Religious practices are the most frequently manifested form of religiosity. They do not exhaust the entire complexity of the phenomenon of faith, but for the candidates for the priesthood, they are undoubtedly one of the key factors in the process of vocational growth. Attending Mass is for them an exceptionally valuable experience, which is confirmed by the first question about church attendance over the last year. As many as $76.8 \%$ of the respondents attended the Eucharist several times a week (assuming that they included Sunday Mass), and 20.8\% attended Mass every Sunday. Thus, a total of $97.6 \%$ of the seminarians declared a constant, weekly participation in the Holy Mass (in 2000 - 94.1\%). The remaining 2.4\% practiced "almost every Sunday" (in $2000-4.1 \%$ ). On the basis of the answers given, it can be seen that for all the candidates the Holy Mass was the most fundamental and inseparable element of their faith. It cannot be ruled out that participation in Mass on Sundays may be motivated by various reasons. In order to produce an explanation of this issue, the respondents were asked the question: "What does Sunday Mass primarily mean to you?" The largest number of the respondents indicated "a religious experience" $62.3 \%$ (in $2000-67.0 \%$ ); the answer "something else" was given by $21.1 \%$ (in 2000 $13.3 \%$ ), in the third place the response was "fulfilling the command of conscience" $-9.3 \%$ (in $2000-14.4 \%$ ), and in the fourth "fulfilling the duty to the Church" $-5.5 \%$ (in $2000-2.9 \%$ ). The answers provided suggest that Mass is becoming slightly less 
personal, although the number of those who are unable to identify their main motive for participating in the Eucharist is increasing.

Apart from belonging to the community of the Church, the main expression of which, is participation in the liturgy, the degree of religiousness of candidates for the priesthood can be determined by asking about their personal and family prayer. This type of prayer is not subject to the pressure of one's environment; it is an expression of individual piety and longing for God. The first in a series of questions concerned the frequency of prayer over the past year. $68.5 \%$ of the candidates for the priesthood prayed two or more times a day (in $2000-66.1 \%$ ), once a day $-20.4 \%$ (in $2000-28.4 \%$ ), from time to time $-4.2 \%$ (in $2000-1.2 \%$ ), every few days $-3.5 \%$ (in $2000-1.4 \%$ ). In total, $88.9 \%$ of the respondents declared praying at least once a day (in $2000-94.5 \%$ ). This means that the number of those who pray every day decreased by 5.6 percentage points compared to the survey conducted 19 years ago.

The set of issues related to the practice of faith in families includes the question of cultivating popular religious traditions at home. The most common custom is to share the wafer at Christmas - 99\% (in $2000-99.3 \%$ ), followed by: blessing food at Easter - 97.2\% (in $2000-98.5 \%$ ), commemoration of all the faithful departed, All Saints' Day and All Souls' Day - 92.7\% (in 2000 - 94.0\%), blessing of the Easter palms - 90.2\% (in $2000-85.9 \%$ ), strict fasting on Ash Wednesday and Good Friday - $87.8 \%$ (in 2000 - 94\%), participation in Corpus Christi processions $85.3 \%$ (in $2000-90.4 \%$ ), Friday fasting $-82.2 \%$ (in $2000-81.8 \%$ ), participation in the Way of the Cross - 70.6\% (in $2000-74.7 \%$ ), singing Christmas carols - 66.4\% (in $2000-72.2 \%$ ), rosary services - 59.4\% (in $2000-68.3 \%$ ), Lenten (Bitter) Lamentations $-54.2 \%$ (in $2000-60.9 \%$ ), May services - 53.8\% (in $2000-68.1 \%$ ), common prayer $-48.6 \%$ (in $2000-42.9 \%$ ) blessing of candles at the Purification - $47.6 \%$ (in $2000-62.6 \%$ ), blessing of herbs on the feast of the Assumption - 40.2\% (in 2000 $39 \%$ ), pilgrimages - 32.9\% (in $2000-43.9 \%$ ), Fatima services - 31.5\% (in 2000 $27.1 \%$ ), reading the Holy Bible - 29\% (in 2000 - 33.4\%) and Divine Mercy Chaplet $28.7 \%$ (in $2000-32.3 \%$ ).

The analysis of the data shows that the number of home religious practices related to most of the above-mentioned customs decreased in the analysed period. The greatest decrease in practices can be observed in terms of participation in: blessing of the candle - 15 percentage points, in May services - 14.3, pilgrimages - 11, rosary services - 8.9, Bitter Lamentations - 6.7 and fasting on Ash Wednesday and Good Friday -6.2 percentage points. At the same time, however, we can observe an increase in some religious practices, especially common prayer - by 5.7 percentage points, Fatima services - by 4.4 and blessing of the Easter palms - by 4.3. The popularity of the services can be explained by the increased recognition of the Fatima apparitions in connection with their 100th anniversary in 2017. 
However, it is overall apparent that the traditional prayers and services in churches and chapels are becoming less appreciated. Perhaps in the following years a shift of practices towards more individual and personal forms will be observed, which may suggest an increased interest in common prayer or observing Friday abstinence from meat.

\subsection{Morality}

Human morality is shaped by many factors, religious and ethical or even social. Therefore, the candidates for the priesthood were asked if they believed that there were precise criteria for what was right or wrong, or if there were no strict and absolute criteria in that matter. The greatest number of the respondents supported the existence of such unambiguous criteria - 42.9\% (in $2000-56.4 \%$ ), against their existence $-28.7 \%$ (in $2000-20.2 \%$ ), $12.8 \%$ of the respondents denied the truth of both statements (in $2000-6.9 \%$ ), and the difficulty in indicating the answers was given by $15.6 \%$ (in $2000-13.8 \%$ ). Thus, there is an evident tendency to doubt the existence of objective rules for distinguishing between good and evil, and perhaps also to relativize our good and bad decisions in certain areas of life.

The respondents were also asked whether the behaviours and attitudes mentioned in the survey were always good or whether they could be good or bad depending on the context of their occurrence. The candidates for the priesthood recognized that the following values were primarily seen as "always good": mercy $95.5 \%$ (in $2000-96.1 \%$ ), forgiveness - 95.2\% (in $2000-95.1 \%$ ), humility - $94.8 \%$ (in $2000-91.1 \%$ ), honesty - 93.8\% (in $2000-93.5 \%$ ), respect for the elderly 91.3\% (in $2000-95.8 \%$ ), obeying moral principles - 88.9\% (in $2000-90.6 \%$ ), truthfulness $-65.4 \%$ (in $2000-69.5 \%$ ), discretion $-61.6 \%$ (in $2000-76.5 \%$ ), interpersonal solidarity $-57.4 \%$ (in $2000-66.7 \%$ ), obedience $-50.5 \%$ (in 2000 $53.8 \%$ ), tolerance $-42.2 \%$ (in $2000-72.1 \%$ ) and stability of beliefs $-38.1 \%$ (in $2000-55 \%)$. In many areas, the views of young people entering the seminary have remained at a similar or slightly lower level of acceptance for the "absolute good" than 20 years ago. The largest decrease in unconditional acceptance was in the field of tolerance - by 29.9 percentage points, stability of beliefs - 16.9 and discretion by 14.9 .

In the field of the negative behaviours, the respondents indicated unequivocal disapproval, regardless of the external situation ("always bad") with regard to the following phenomena: accepting bribes - 96.2\% (in 2000 - 93.5\%), giving bribes $90.7 \%$ ( in $2000-84.2 \%$ ), theft - $81 \%$ (in $2000-83.6 \%$ ), buying pirated copies of music recordings - 72\% (in $2000-53.2 \%$ ), buying pirated copies of computer programmes - $71.6 \%$ (in $2000-54.1 \%$ ), lies - 55\% (in $2000-58.2 \%$ ) and primarily taking care of one's own business $-52.9 \%$ (in $2000-67 \%$ ). 


\subsection{Core Calues}

The respondents were asked to list the five most important values or goals they wish to achieve in their lives. When asked what above all gives meaning to human life, deep religious faith was most often declared - 88.2\% (in 2000 - 92\%). In both studies, this answer came in the first place but the order of the remaining answers was different. In 2019, love and great feelings came second - 57.1\% (in $2000-40.1 \%$ and 5 th place). In the third position, the respondents indicated finding their own place in the society and the feeling that one is useful and needed - 48.8\% (in $2000-56.9 \%$ and the 2 nd place). Family happiness was listed fourth $-46.4 \%$ (in $2000-31.6 \%$ and the 7 th place). Gaining human trust and friends came in the fifth position $-41.9 \%$ (in $2000-50.6 \%$ and the 3 rd place).

The subsequent values were as follows:

- 6th place - activity and pursuit of the chosen goal - 32.9\% (in $2000-41.4 \%$ and the 4 th place),

- 7th place - the work you like - 23.9\% (in $2000-32.6 \%$ and the 6th place),

- 8th place - developing your individuality and personal style as well as the ability to be oneself $-20.8 \%$ (in $2000-16.4 \%$ and the 10 th place),

- 9th place - leaving a long-term legacy - 19\% (in $2000-19.7 \%$ and 9th place),

- 10th place - education and the pursuit of knowledge - 16.3\% (in $2000-23.7 \%$ and the 8th place)

- 11th place - believing in a great idea - $14.9 \%$ (in $2000-11.5 \%$ and the 11th place).

As the lowest values in the ranking, the respondents placed the wealth of life experiences, tasting everything, even at the cost of distress - 2.1\% (in $2000-1.1 \%$ ), money, well-being and life comfort $-2.8 \%$ (in $2000-1.6 \%$ ) and a quiet life without any surprises $-2.8 \%$ (in $2000-2.9 \%$ ).

\section{Vision of the Church}

\subsection{The Essence of the Church}

The Church is a divine and human reality - it contains both the visible and the spiritual. For this reason, the description of the Church in sociological terms primarily refers to her institutional dimension. Nevertheless, the candidates for the priesthood were asked about their understanding of the Church.

The first of the questions given to the respondents was general: "What does the Catholic Church primarily mean to you?" The respondents could choose only 
one out of eight answers. For the majority of the surveyed group, the Church was first of all a community of believers - 73.7\% (in $2000-76.5 \%$ ), then, with much lower indications: an institution that protects faith and customs - 9\% (in $2000-7.7 \%$ ), a sacred institution with the Pope and the clergy - 6.6\% (in $2000-8.5 \%$ ), a global organization with certain secular goals as well - $0.3 \%$ (in $2000-1 \%$ ), something else $-8.3 \%$ (in $2000-4.4 \%$ ), hard to say $-1.7 \%$ (in $2000-1 \%$ ). Basically, the distribution of the answers was consistent with the research of the year 2000, although the group of those who were unable to clearly define their vision of the Church has increased significantly.

Can you be a religious Catholic without the Church? The thesis, which is now quite often formulated by liberal media, did not gain much support in the eyes of the candidates for the priesthood. They were to respond to this issue in relation to two definitions: the Church as the People of God and the Church as an institution. According to the answers received, it is impossible to be a Catholic without the Church understood as the People of God - this was what $91.3 \%$ of respondents believed in (in $2000-90.3 \%$ ). However, $3.5 \%$ saw such a possibility (in $2000-3.8 \%$ ), and $4.2 \%$ declared that it was difficult to answer (in $2000-5.1 \%$ ). If, however, we look at the Church as an institution, the necessity of her existence was declared by $70.6 \%$ of the respondents (in $2000-60.6 \%$ ), an opposite opinion was expressed by $11.8 \%$ (in $2000-16.5 \%$ ), a difficulty in giving an answer was indicated by $17 \%$ of the respondents (in $2000-21.4 \%$ ).

\subsection{The Essence of the Priestly Service}

The vocation to the priesthood, as any vocation, is a kind of mystery. We are dealing here with the action of God and the response of a free man to His call.

The candidates for the priesthood were asked about the constitutive dimension of their vocation. The nature of the priesthood was characterized by several basic terms, and the surveyed were asked to identify the one that best suits their aspirations. Apart from choosing one of the terms describing the priesthood, the respondents could mark the box "something else." The most frequently indicated answer was the concept of service - 72\% (in $2000-68.1 \%$ ), then: dedication $-13.8 \%$ (in $2000-19.5 \%$ ), responsibility - $4.2 \%$ (in $2000-2.1 \%$ ), privilege $-1.7 \%$ (in $2000-1.5 \%$ ), challenge $-1.4 \%$ (in $2000-1.9 \%$ ), example $-1 \%$ (in $2000-0.6 \%$ ), profession - $0 \%$ (in $2000-0.3 \%$ ). The answer "something else" was chosen by $4.8 \%$ of the respondents (in $2000-4.5 \%$ ). So for the past twenty years there has been no fundamental change in the understanding of the central idea of the priesthood. However, there has been a slight increase in terms such as service, dedication and responsibility, which would mean that today's candidates are more conscious of their calling and aware of the difficulties that accompany this path of life. 


\subsection{Pastoral Passions of Future Priests}

At the source of the vocation there is also the conviction about the need to support pastoral work by new priests. In the light of this readiness to undertake the priestly ministry, it seems extremely interesting to ask what type of work in the Church the future candidates for ordination wish to devote themselves to.

The largest group of the respondents saw their priestly service as work in a parish $-45.3 \%$ (in $2000-36.4 \%$ ). $18.3 \%$ of the respondents (in $2000-17.3 \%$ ) did not yet think about it. Others saw themselves respectively: in special pastoral ministry of some social or professional circles, such as the army, the sick, prisoners, etc. - $11.4 \%$ (in $2000-11.7 \%)$, in something else - 7.3\% (2000 - 4.4\%), in academic work - 5.2\% (in $2000-5.3 \%$ ), in mission ministry - 5.2\% (in $2000-8 \%$ ), working in church administration, e.g. in the curia $-2.4 \%$ (in $2000-2.4 \%$ ), in catechetical work $-2.4 \%$ (in $2000-7.8 \%$ ), in charity work and helping the poor - 1.7\% (in $2000-5.4 \%$ ). The percentage of those declaring their willingness to do missionary and charity work decreased significantly. This might be related to entrusting these duties to specialised agencies of the Church, charities, missionary orders, etc. This work is less associated with the parish ministry, which is the main goal striven for by the candidates for the priesthood. There was also a clear decline in those willing to do catechetical work. Their reluctance may result from their awareness of difficulties that accompany teaching religious instruction in schools as well as the low prestige of the teacher of religious instruction.

\section{Conclusion}

Over the past twenty years, there has been an evident decrease in vocations to the priesthood $\left(2000-925 ; 2019-300^{6}\right)$. The seminarians are generally young men although there is a noticeable rise in the candidates' age since nowadays more men aged about 30 choose to become priests. Their typical education is the completion of high school and obtaining the final certificate, which is called "matura" in Poland. On the other hand, the number of seminarians who have completed higher education or have work experience is increasing. The candidates' motivation for entering the seminary is to fulfil the inner need to deepen their relationship with God. The vast majority of them served as altar boys, and some took an active part in religious communities and movements. For almost three quarters of the respondents,

6 This number consists of 289 surveyed candidates and 11 candidates from the seminaries which did not send back the surveys. 
the Church is first and foremost a community of believers, and for the vast majority the priesthood means service.

The respondents are not deprived of a critical view of the Church in which they wish to minister in the future. More than half of them believe that contacts between priests and the faithful are too superficial, more than a third express the opinion that the Church does not stand up to the conditions and challenges of the contemporary world. The candidates for the priesthood have been brought up in the world of electronics and the Internet, which is why they strongly believe that they should use the media in pastoral ministry.

The image of the candidate for the priesthood that emerges from the research is far from being ideal. Yet, this is just the beginning of the way to the priesthood as the studies and priestly formation last six years. God's grace and personal efforts can considerably help change this picture.

Translated by Agnieszka Krocin

\section{Bibliography}

Pawlina, K., Kandydaci do kapłaństwa trzeciego tysiąclecia (Warszawa: Wydawnictwo Sióstr Loretanek 2002).

Pawlina, K., Powołania kapłańskie AD 2020 (Warszawa: Wydawnictwo Naukowe Collegium Bobolanum 2020). 
